\title{
ANALISIS RESEPSI MAHASISWA ILMU KOMUNIKASI UNIVERSITAS SEMARANG TERHADAP TAYANGAN IKLAN TELEVISI LAYANAN SMS PREMIUM VERSI RAMALAN PARANORMAL
}

\author{
Febrian \\ (febrian5477@gmail.com) \\ ((Mahasiswa S 1 Program Studi Ilmu Komunikasi Universitas Semarang)
}

\begin{abstract}
This study aims to understand the audience reception of cultural horoscope, forecasts and the occult are sold through premium SMS services. Basic theory used in this study is the cultivation theory of McQuail (1996) which states that television become a major tool in which the media or the television audience to learn about society and culture environment. In other words, the perception of what our minds awakened about society and culture is largely determined by the television. The research method qualitative descriptive used is a interpretive perspective. Research was conducted in the city of Semarang. Informants in this study were students of the University of Semarang science communication. Concluded that the analysis of other research has answered this reception, where there are three positions in the analysis of audience reception that is the position of the dominant readings, readings that are negotiated and oppositional readings. From this study it can be concluded if the ad is a Premium SMS content that contents can not be held responsible, this can be seen from the researcher interviewed informants in the field.
\end{abstract}

Keywords : Perspektif Interpretatif, Teori Cultivation, Analisis Reception

\section{Pendahuluan}

Program Short Message Service (SMS) Premium seperti ini berbeda dengan SMS pada umumnya. Saat ini jenisnya sudah sangat beragam. Ada berita, skor pertandingan, profil publik figur/artis, kencan virtual/chatting, humor, atau yang sedang menjadi trend saat ini adalah ramalan. Seluruhnya bisa diperoleh cukup melalui SMS. Konsumen tinggal mengirim sebuah kata kunci yang sudah dipromosikan untuk sebuah layanan ke sebuah nomor yang biasanya memiliki angka empat digit. Setelah itu konsumen akan menerima balasan sesuai permintaan. Panjang muatan balasan biasanya tidak lebih dari 160 karakter. Ini adalah jumlah karakter maksimal pengiriman dan penerimaan SMS dalam sebuah ponsel, yang tidak hanya berlaku untuk premium. Dalam aturan SMS umum jumlah ini pula yang berlaku. Jika lebih dari 160 karakter maka karakter sisa akan terkirim melalui SMS berikutnya. Seiring dengan perkembangan, SMS premium akhirnya harus menggunakan proses pendaftaran. Dengan kata lain, konsumen diharuskan berlangganan untuk mendapatkan akses dan mengikuti layanan. Akan tetapi, proses pendaftaran tidak memiliki acuan yang baku atau standar. Ada yang menggunakan kata kunci ' $R E G$ ', 'Daftar', atau 'SUB'. Ketiga kata kunci ini/keyword, digunakan untuk berlangganan. Sekali anda mengirim tulisan itu ke nomor tertentu, maka anda langsung dianggap sebagai pelanggan. 
Sedangkan untuk berhenti berlangganan disediakan kata kunci 'UNREG', 'Stop', atau 'UNSUB'. Secara normal, setelah mengirim kata kunci tersebut, maka seorang konsumen tidak lagi dianggap sebagai pelanggan. Ada pula kombinasi ' $R E G$ ON' dan ' $R E G O F F$ '. Istilah yang pertama untuk berlangganan dan istilah yang kedua untuk berhenti.

SMS Premium dewasa ini merupakan salah satu topik yang kerapkali diperbincangkan. Layanan hiburan yang lebih dikenal dengan nama 'ketik reg spasi' ini hampir setiap hari menghiasi layar kaca dengan berbagai jenis/variannya. Seperti yang disajikan televisi sebagai menu/hidangannya kepada khalayak, tayangan iklan layanan SMS premium bermunculan menawarkan hadiahhadiah atau menawarkan berbagai macam isi yang menarik seperti cerita lucu, cerita horor, horoscope atau ramalan yang dipandu oleh tukang ramal terkenal seperti Deddy Corbuzier, Mbah Roso, Ki Joko Bodo dan lain sebagainya.

Fenomena tersebut merupakan suatu hiburan baru yang menarik dan menyenangkan, tetapi media memiliki peran dalam mengkomunikasikan iklannya kepada masyarakat yaitu dengan tujuan untuk membentuk dan mempengaruhi pola pikir masyarakat supaya mau ikut dalam layanan tersebut.

Selanjutnya, SMS Premium merupakan layanan SMS yang disediakan oleh penyedia konten (content provider) dengan berbagai tawaran konten. Layanan itu sendiri adalah layanan SMS yang tarifnya di atas normal dengan menggunakan nomor pendek 4 digit supaya mudah dihafal oleh masyarakat. Tarifnya mulai dari Rp500,00 sampai Rp2000,00 per SMS yang dikelola oleh content provider (penyedia konten) dan bekerja sama dengan operator telekomunikasi. Dalam hal ini mereka membagi keuntungan dalam pola tertentu.

Layanan SMS Premium dapat terselenggara dengan adanya kerjasama antara operator telekomunikasi seluler dengan content provider. SMS Premium memungkinkan kita untuk mendapatkan informasi terbaru tentang berita, olah raga, dunia hiburan, zodiak, ramalan jodoh dan karir berdasarkan info dari pakar-pakar yang bersangkutan.

Pada era modern seperti sekarang ini ramalan/mantra gaib dan primbon seperti itu masih laku keras dijual ke masyarakat. Mungkin hal tersebut dianggap berbau spiritual oleh masyarakat, serta merupakan warisan kebudayaan dari leluhur yang masih melekat erat dihati masyarakat Indonesia, sehingga layanan SMS Premium yang berbau ramalan-ramalan laris manis dipasaran. Dalam hal ini media menggunakan budaya yang sudah melekat di masyarakat sebagai unsur dasar namun media mencoba membentuk dan mengubahnya dengan gaya baru yang identik dengan budaya popular yang canggih, modern, ringkas, mudah, dan serba cepat. Sementara itu, walaupun SMS ramalan ini terkesan menipu dan membodohi masyarakat tetapi tetap saja masyarakat menggunakan layanan ini.

Hal ini tidak lepas dari dukungan media yang berulang kali menayangkan iklan layanan SMS Premium kategori ramalan dan semakin beragam jenis iklan ini di televisi. Isi iklan tersebut secara tidak langsung menyatakan bahwa informasi yang disediakan content provider diperlukan masyarakat untuk menjadi cerdas. Oleh karenanya, mayarakat beranggapan bahwa untuk menjadi cerdas mereka harus melahap layanan yang ditawarkan content provider. Iklan SMS 
Premium/dikenal dengan ' $k e t i k$ reg spasi' cukup banyak menuai diskusi dan sinisme terhadap layanan ini, yang mana meminta penghapusan layanan ini. Hiburan dan layanan SMS Premium ini memang menjadi sebuah 'demam' yang melanda Indonesia. Media memiliki peran penting dalam mengkonstruksikan realitas dan mempengaruhi pola pikir khalayak.

Khalayak dipengaruhi media dengan iklan-iklan layanan SMS Premium yang menawarkan sejuta hiburan dan hadiah yang dikemas dengan cara yang sederhana dan menarik. Dalam iklannya para selebritis dan orang-orang terkenal seperti $\mathrm{Ki}$ Joko Bodo mengajak khalayak untuk ikut mendaftar dan menikmati layanan SMS Premium tersebut. Namun disisi lain, hal ini menyebabkan terjadinya pola hidup konsumtivisme seperti yang ditawarkan oleh media. Untuk itulah, penelitian ini ingin melihat resepsi khalayak atas tayangan iklan televisi tentang layanan SMS premium versi ramalan paranormal

\section{Tinjauan Pustaka}

\section{Paradigma Interpretif}

Tujuan dari interpretive tidak untuk menemukan hukum yang mengatur kejadian-kejadian, tetapi menemukan cara-cara setiap individu dalam memahami pengalaman mereka sendiri. Paradigma ini menggambarkan proses pikiran aktif untuk mengingat kembali pengalaman individu atas kejadian apapun yang dialaminya.

Paradigma interpretif menghormati subyektivisme atau keunggulan pengalaman individu. Ketika individuindividu menginterpretasikan atau memaknai pengalamannya atas keterbukaan diri dan ketidakpastian dalam berkomunikasi antar pribadi di lingkungan baru, maka cara pandang subyektif dari individu-individu sebagai subyek penelitian yang dipakai untuk mengkonstruksikan realitas yang dialaminya. Dengan demikian, melalui paradigma interpretif dapat dihasilkan suatu deskripsi, wawasan, dan penjelasan peristiwa sehingga sistem interpretasi dan makna dapat diungkapkan (Littlejohn, 1999: 199).

\section{Cultivation Theory}

Teori kultivasi sangat menonjol dalam kajian mengenai dampak media televisi terhadap khalayak. Bagi Gerbner, dibandingkan media massa yang lain, televisi telah mendapatkan tempat yang sedemikian signifikan dalam kehidupan sehari-hari sehingga mendominasi "lingkungan simbolik" kita, dengan cara menggantikan pesannya tentang realitas bagi pengalaman pribadi dan sarana mengetahui dunia lainnya (McQuail, 1996 : 254).

Gerbner menyebut pengaruh ini dengan pengembangan karena televisi diyakini sebagai agen penyetara dalam budaya, atau mengembangkan suatu budaya. Analisis pengembangan berkaitan dengan kesuluruhan pola yang dikomunikasikan secara kumulatif oleh televisi dalam periode keterbukaan yang panjang, bukan oleh isu atau pengaruh tertentu. Dengan kata lain, ini bukanlah sebuah teori tentang 'pengaruh' media individu, tetapi sebuah pernyataan tentang budaya sebagai sebuah kesatuan. Teori ini tidak berkaitan dengan apa yang dapat dilakukan oleh strategi atau kampanye apapun, tetapi dengan pengaruh banyaknya strategi dan kampanye.

Menurut teori kultivasi ini, televisi menjadi media atau alat utama dimana para penonton televisi itu belajar tentang masyarakat dan kultur dilingkungannya. Dengan kata lain, persepsi apa yang terbangun di benak kita tentang masyarakat dan budaya 
sangat ditentukan oleh televisi. Ini artinya, melalui kontak kita dengan televisi kita belajar tentang dunia, orang-orangnya, nilai-nilainya serta adat kebiasannya.

\section{Tiga Posisi Penonton Dalam Analisis Resepsi}

Dalam studi ini terdapat tiga jenis atau dapat dikatakan sebagai posisi penonton dalam analisis resepsi. Stuart Hall menjelaskan resepsi yaitu bagaimana proses pendekodean penonton berlangsung di dalam media. Ia melihat bahwa seorang khalayak melakukan pendekodean terhadap pesan melalui tiga sudut pandang atau posisi. Pertama, posisi pembacaan dominan (dominant-hegemonic position). Posisi ini terjadi ketika produsen acara menggunakan kode-kode yang bisa diterima secara umum, sehingga penonton akan menafsirkan dan membaca pesan/tanda itu dengan pesan yang sudah diterima secara umum tersebut. Untuk situasi ini, secara hipotesis dapat dikatakan tidak terjadi perbedaan penafsiran antara produsen dengan penonton, serta di antara penonton sendiri yang beragam secara hipotesis juga dapat dikatakan mempunyai penafsiran atau membaca tanda yang sama. Kedua, pembacaan yang dinegosiasikan (negotiated code/position). Pada posisi kedua ini, tidak adanya pembacaan dominan. Kondisi yang terjadi berupa kode apa saja yang disampaikan produsen, ditafsirkan secara terus-menerus diantara kedua belah pihak. Produsen di sini juga menggunakan kode atau kepercayaan politik yang dipunyai oleh khalayak, tetapi ketika diterima oleh penonton tidak dibaca dalam pengertian umum, tetapi khalayak akan menggunakan kepercayaan dan keyakinannya tersebut dan dikompromikan dengan kode-kode yang disediakan oleh produsen.

Ketiga, pembacaan oposisi (oppositional code/position). Posisi pembacaan dari jenis yang ketiga ini merupakan kebalikan dari posisi yang pertama. Pada posisi pembacaan pertama, khalayak disediakan penafsiran yang umum dan tinggal pakai secara umum pula, serta secara hipotesis sama dengan apa yang ingin disampaikan oleh produsen. Sementara itu, dalam posisi ketiga ini, penonton akan menandakan secara berbeda atau membaca secara berseberangan dengan apa yang ingin disampaikan oleh khalayak tersebut. Pembacaan oposisi ini muncul kalau produsen tidak menggunakan kerangka acuan budaya atau kepercayaan politik khalayak pembacanya, sehingga penonton akan menggunakan kerangka budaya atau politiknya sendiri (Hall dalam Lowe dan Willis, 1986: 129-138).

\section{Expectancy-Value Theory}

Kepuasan yang kita cari dari media ditentukan oleh sikap kita terhadap media. Keyakinan kita tentang media tertentu apa yang dapat memuaskan kita dan penilaian tentang material ini. Sebagai contoh jika kita percaya bahwa komedi situasi memberikan hiburan dan kita senang dihibur, kita akan mencari kepuasan dari kebutuhan akan hiburan kita dengan menonton komedi situasi. Sebaliknya, jika kita percaya bahwa komedi situasi memberikan sebuah pandangan hidup yang tidak realistis dan kita tidak menyukai hal ini, kita tidak akan menontonnya.

\section{Uses and Gratification Theory}

Salah satu teori yang paling populer tentang komunikasi massa adalah pendekatan penggunaan dan kepuasaan (uses and gratification). 
Pendekatan ini berfokus pada konsumen-anggota-audiens-ketimbang pada pesannya. Teori tersebut sering digunakan sebagai kerangka teori dalam mengkaji realitas komunikasi massa adalah uses and gratifications. Pendekatan uses and gratifications menekankan riset komunikasi massa pada konsumen pesan atau komunikasi dan tidak begitu memperhatikan mengenai pesannya. Kajian yang dilakukan dalam ranah uses and gratifications mencoba untuk menjawab pertanyan : "Mengapa orang menggunakan media dan apa yang mereka gunakan untuk media?" (McQuail, 2002 : 388).

\section{The Effect Tradition Theory}

Teori tentang pengaruh komunikasi massa telah mengalami perkembangan yang besar pada abad ini. Sebelumnya, para peneliti percaya pada 'peluru ajaib' teori pengaruh komunikasi. Individu diyakini sangat terpengaruh oleh pesan-pesan media karena media dianggap sangat kuat dalam membentuk opini masyarakat. Selanjutnya menurut (Raymond Bauer dalam LittleJohn, 2009: 423) mengamati bahwa audiens sulit untuk dibujuk dan bahkan menyebutnya dengan 'keras kepala'. Ia menolak gagasan bahwa pengaruh jarum suntik yang langsung terjadi antara pelaku komunikasi dan audiens serta menyatakan bahwa banyak variabel yang berinteraksi untuk membentuk pengaruh dalam berbagai cara. Bauer telah membayangkan akan ada banyak penelitian tentang pengaruh media, dengan desakannya bahwa banyak faktor yang berpengaruh yang ada dari media.

\section{Dependence Theory}

Pendekatan penggunaan dan kepuasan adalah sebuah teori pengaruh terbatas. Dengan kata lain, pendekatan ini memberikan lebih banyak kendali pada individu atas bagaimana mereka menggunakan media dalam kehidupan mereka. Walaupun para peneliti media membaginya hanya pada seberapa kuatnya media tersebut, beberapa peneliti membantah bahwa modelmodel pengaruh terbatas dan pengaruh kuat tidak sepenuhnya bertentangan. Teori ketergantungan bergerak selangkah lebih maju dalam menunjukan bagaimana keduanya menjelaskan pengaruh media. Sejauh dengan teori penggunaan dan kepuasan, teori ketergantungan memperkirakaan bahwa anda bergantung pada informasi media untuk memenuhi kebutuhan tertentu dan mencapai tujuan tertentu. Akan tetapi, kita tidak bergantung pada semua media. Ada dua faktor yang menentukan akan seberapa bergantungnya anda pada media (Ball Rokeach dan DeFleur dalam Littlejohn dan Foss, 2009: 428).

\section{Popular Culture}

Pendekatan terhadap budaya pop termasuk televisi adalah pendekatan yang mengakui budaya pop sebagai 'sebuah medan pertarungan' dan walaupun mengakui 'kekuasaan terhadap kekuatan dominasi', justru memilih mengarahkan perhatiannya pada 'taktik-taktik popular yang dengan itu kekuatan-kekuatan ini diatasi, dihindarkan, atau dilawan'(Fiske dalam Storey, 2008: 33). Dengan kata lain, 'alih-alih semata-mata menelusui proses penggabungan, pendekatan ini lebih memilih untuk meniliti vitalitas dan kreativitas popular yang menggabungkan kebutuhan tersebut'. Lebih lanjut, alih-alih berkonsentrasi pada praktik-praktik ideologi dominan yang marak dan membahayakan, pendekatan ini mencoba memahami perlawanan dan penghindaran sehari- 
hari yang membuat ideologi itu bekerja sedemikian keras dan bertubi-tubi untuk mempertahankan dirinya sendiri dan nilai-nilainya.

\section{Metodologi Penelitian \\ 1. Jenis Data}

Seperti diketahui bahwa sumber data dalam penelitian kualitatif terdiri dari beragam jenis, bisa berupa orang, peristiwa, tempat dan lokasi, benda, serta dokumen dan arsip. Secara umum strategi pengumpulan data dalam penelitian kualitatif yaitu dengan teknik pengumpulan data yang bersifat interaktif menurut Goetz dan LeComte (dalam Sutopo, 2002: 48). Teknik interaktif ini meliputi wawancara mendalam dan observasi.

\section{Metode Pengumpulan Data}

Dalam penelitian ini, peneliti menggunakan teknik wawancara tidak terstruktur atau wawancara mendalam (indepth interview), yaitu cara mengumpulkan data atau informan dengan cara langsung bertatap muka dengan informan untuk mendapatkan data yang lengkap dan mendalam (Kriyantono, 2009: 98). Hal ini dilakukan unutk mempermudah peneliti mengungkap interpretasi informan tehadap tayangan iklan 'SMS Premium versi paranormal'. Wawancara dilakukan secara informal dengan tujuan untuk memperoleh bentukbentuk informasi tertentu dari semua informan. Sedangkan susunan kata dan urutannya disesuaikan dengan ciri-ciri tiap informan. Wawancara yang tidak terstruktur bersifat santai atau luwes. Susunan kata dan pertanyaan dapat diubah sewaktu-waktu pada saat wawancara berlangsung (Moleong, 2005: $187 \& 190)$.

\section{Hasil dan Pembahasan}

Dalam pembahasan di sub bab ini Peneliti akan mengutarakan pengertian iklan dan sedikit seluk beluknya. Iklan atau advertising dapat didefinisikan sebagai "any paid form of non personal communication about an organization, product, service, or idea by an identified sponsor" (setiap bentuk komunikasi non personal mengenai suatu organisasi, produk, servis, atau ide yang dibayar oleh satu sponsor yang diketahui). Adapun maksud 'dibayar' pada definisi tersebut menunjukkan fakta bahwa ruang dan waktu bagi suatu pesan iklan pada umumnya harus dibeli. Maksud kata 'non personal' berarti suatu iklan melibatkan media massa ( $\mathrm{TV}$, radio, majalah, koran) yang dapat mengirimkan pesan kepada sejumlah besar kelompok individu pada saat bersamaan. Dengan demikian, sifat non personal iklan berarti pada umumnya tidak tersedia kesempatan untuk mendapatkan umpan balik yang segera dari penerima pesan. Karena itu, sebelum pesan iklan dikirimkan, pemasang iklan harus betul-betul mempertimbangkan bagaimana audiens akan menginterpretasikan dan memberikan respons terhadap pesan iklan yang dimaksud (Morissan, 2010 : 18). Demikian pula dengan SMS Premium Versi Ramalan Paranormal yang menggunakan televisi sebagai media penyampaian pesan antara produsen iklan dalam hal ini content provider dengan calon konsumennya.

Hasil dari wawancara yang Peniliti tanyakan terhadap ke empat Informan menunjukkan bahwa semua Informan sepakat bahwa pengertian SMS Premium secara umum itu adalah SMS berlangganan dengan melakukan registrasi sebelumnya yang menggunakan keyword tertentu dan biasanya di awali dengan kata REG. Sedangkan untuk melakukan pembatalan berlangganan biasanya di 
awali dengan kata UNREG atau STOP. Berbicara mengenai varian iklan SMS Premium yang muncul di televisi, semua Informan berpendapat jika SMS Premium tersebut banyak jenisnya dan tidak hanya tentang paranormal saja. Peneliti pernah melihat contoh-contoh iklan SMS Premium, yaitu ada ramalan, cinta, weton, chat n' date, game, wallpaper, ringtone, aura, artis, bola dan masih banyak lagi yang lainnya. Biasanya iklan diciptakan oleh produsen suatu produk dengan tujuan agar calon konsumennya tertarik untuk menggunakan produk yang telah diiklankan. Hal ini bisa dikatakan bahwa iklan yang dibuat harus bisa mempengaruhi penontonnya agar dapat menjawab keinginan produsen tersebut. Tapi lain halnya dengan beberapa Informan yang diwawancarai oleh Peneliti. Sebagian tidak percaya dengan iklan tersebut namun ada salah satu Informan yang mempercayai iklan SMS Premium Versi Ramalan Paranormal. Di tengah maraknya perkembangan teknologi tidak jarang masyarakat masih memegang teguh produk-produk budaya yang bisa dikatakan "kuno". Ilmu-ilmu tradisional tampaknya masih belum bisa disingkirkan begitu saja oleh masyarakat, termasuk masyarakat Jawa. Saat ini ilmu-ilmu tradisional masih berjalan beriringan dengan kecanggihan teknologi, salah satunya adalah penggunaan primbon. Bahkan tak jarang masyarakat Jawa beranggapan bahwa primbon adalah sumber bacaaan untuk menuju keselamatan dan kebahagian bagi pembacanya.

Dalam pengertian umum budaya primbon adalah semacam perhitungan orang jawa atau pengetahuan orang jawa, hal ini sudah ada sejak ratusan tahun yang lalu dan bahkan sampai sekarang masih banyak yang mempercayainya (Soemodidjojo, 2007: 13). Sedangkan untuk pengertian ramalan, biasanya adalah prediksi mengenai suatu peristiwa yang akan datang dan biasanya adalah masa depan seseorang (Soemodidjojo, 2007: 35). Menurut Kamus Besar Bahasa Indonesia / KBBI, pengertian klenik adalah hal yang bersifat sangat rahasia, yang tidak masuk akal dan biasanya berkaitan dengan dukun.

Menurut Gerbner, cultivation theory sangat menonjol dalam kajian mengenai dampak media televisi terhadap khalayak. Dibandingkan media massa yang lain, televisi telah mendapatkan tempat yang sedemikian signifikan dalam kehidupan sehari-hari sehingga mendominasi "lingkungan simbolik" kita, dengan cara menggantikan pesannya tentang realitas bagi pengalaman pribadi dan sarana mengetahui dunia lainnya (Gerbner dalam McQuail, 1996 : 254).

Cultivation theory di awal perkembangannya lebih memfokuskan kajiannya pada studi televisi dan audiens, khususnya memfokuskan pada tema-tema kekerasan di televisi. Tetapi dalam perkembangannya, ia juga bisa digunakan untuk kajian di luar tema kekerasan. (Dominic, 1990: 143).

Bagian yang lain dari penelitian ini adalah mencoba untuk menentukan pengaruh tindakan konsumsi masyarakat pada iklan di televisi tentang tayangan iklan SMS premium. Hasilnya menunjukkan bahwa penonton kelas berat cenderung lebih mempercayai kata-kata paranormal yang mengisi iklan SMS premium tersebut daripada yang dilakukan oleh penonton kelas ringan. Penelitian pengembangan seperti ini menemukan bahwa ada pengaruh yang turun dari televisi ke seluruh budaya. Televisi bukanlah sebuah dorongan untuk perubahan layaknya televisi sebagai dorongan untuk stabiltas dan keseragaman. 
Begitu juga dengan ke empat Informan yang diwawancarai oleh Peneliti. Jawaban yang ditemukan oleh Peneliti di lapangan sangat beragam. Ini sangat cocok sekali dengan teori analisis resepsi yang di gagas oleh Stuart Hall. Stuart Hall menjelaskan resepsi yaitu bagaimana proses pendekodean penonton berlangsung di dalam media. Ia melihat bahwa seorang khalayak melakukan pendekodean terhadap pesan melalui tiga sudut pandang atau posisi.

Pertama, posisi pembacaan dominan (dominant-hegemonic position). Posisi ini terjadi ketika produsen acara menggunakan kode-kode yang bisa diterima secara umum, sehingga penonton akan menafsirkan dan membaca pesan/tanda itu dengan pesan yang sudah diterima secara umum tersebut. Untuk situasi ini, secara hipotesis dapat dikatakan tidak terjadi perbedaan penafsiran antara produsen dengan penonton, serta di antara penonton sendiri yang beragam secara hipotesis juga dapat dikatakan mempunyai penafsiran atau membaca tanda yang sama. Hal ini terjadi ketika produsen menggunakan kode-kode profesional sehingga hampir tidak ada beda penafsiran yang tajam di antara penonton. Produsen bisa jadi menggunakan pula kode-kode budaya, posisi politik yang diyakini dan menjadi kepercayaan dari penonton, sehingga ketika pesan dalam bentuk kode-kode itu sampai di tangan penonton, akan terjadi kesesuaian. Apa yang ditandakan oleh produsen, ditafsirkan dengan pembacaan umum oleh khalayak penonton.

Kedua, pembacaan yang dinegosiasikan (negotiated code/position). Pada posisi kedua ini, tidak adanya pembacaan dominan. Kondisi yang terjadi berupa kode apa saja yang disampaikan produsen, ditafsirkan secara terus-menerus diantara kedua belah pihak. Produsen di sini juga menggunakan kode atau kepercayaan politik yang dipunyai oleh khalayak, tetapi ketika diterima oleh penonton tidak dibaca dalam pengertian umum, tetapi khalayak akan menggunakan kepercayaan dan keyakinannya tersebut dan dikompromikan dengan kode-kode yang disediakan oleh produsen.

Ketiga, pembacaan oposisi (oppositional code/position). Posisi pembacaan dari jenis yang ketiga ini merupakan kebalikan dari posisi yang pertama. Pada posisi pembacaan pertama, khalayak disediakan penafsiran yang umum dan tinggal pakai secara umum pula, serta secara hipotesis sama dengan apa yang ingin disampaikan oleh produsen. Sementara itu, dalam posisi ketiga ini, penonton akan menandakan secara berbeda atau membaca secara berseberangan dengan apa yang ingin disampaikan oleh khalayak tersebut. Pembacaan oposisi ini muncul kalau produsen tidak menggunakan kerangka acuan budaya atau kepercayaan politik khalayak pembacanya, sehingga penonton akan menggunakan kerangka budaya atau politiknya sendiri (Hall dalam Hall, Hobson, Lowe dan Willis, 1986: 129138).

\section{Kesimpulan}

Penelitian mengenai pemaknaan mahasiswa Ilmu Komunikasi, FTIK, Universitas Semarang ini mengkaji dengan menggunakan metode analisis resepsi. Pada dasarnya penelitian ini bertujuan untuk mengetahui pemaknaan mahasiswa setelah melihat iklan SMS Premium Versi Ramalan Paranormal. Setelah melakukan wawancara akan diketahui tiga posisi penonton yang ada dalam analisis resepsi. 
Memperlihatkan realitas bahwa jalan untuk keluar dari masalah adalah pergi ke dukun. Memberitahu kepada masyarakat bahwa "wajar" kita mempercayai dukun, mistis dan klenik. Media seakan menuntun khalayaknya untuk menaruh kepercayaan kepada mistis dan takhayul yang sangat bertentangan dengan ajaran agama manapun.

Budaya yang sudah ada di masyarakat seperti Primbon dan sebagainya semuanya ditawarkan dan dijual belikan dalam bentuk layanan SMS premium. Kebudayaan tersebut diperlakukan layaknya komoditas yang bernilai jual tinggi di masyarakat.

\section{Daftar Pustaka}

Dominic, Joseph R. 1990. The Dynamick of Mass Communication. New York: Random House.

H. B. Sutopo. 2002. Metodologi Penelitian Kualitatif, Dasar Teori dan Aplikasi Praktisnya. Surakarta, Indonesia: Sebelas Maret University Press.

Hall, Stuart., Dorothy Hobson, Andrew Lowe and Paul Willis (Eds.). 1986. Culture, Media, Language. London: Hutchinson.

Lexy Moleong. 2005. Metodologi Penelitian Kualitas.
Bandung: PT. Remaja Rosdakarya.

Littlejohn, S. W. 1999. Theories of Human Communication (Sixth Edition). New Mexico: Wadsworth Publishing Company.

Littlejohn, S. W and Karen A. Foss. 2009. Teori Komunikasi (Edisi 9 terjemahan oleh Mohammad Yusuf Hamdan). Jakarta : Salemba Humanika.

McQuail, Dennis. 1996. Teori Komunikasi Massa Suatu Pengantar. Jakarta: Erlangga. 2002. Teori Komunikasi Massa, Jakarta : Erlangga.

Morissan. 2010. Periklanan : Komunikasi Pemasaran Terpadu. Jakarta : Kencana Prenada Media Group.

Rachmat Kriyantono. 2009. Teknik Praktis Riset Komunikasi. Jakarta: Kencana Prenada Media Group.

Soemodidjojo. 2007. Kitab Primbon Betaljemur Adammakna. Yogyakarta : Soemodidjojo Mahadewa.

Storey, John. 2008. Cultural Studies dan Kajian Budaya Pop (Edisi terjemahan oleh Layli Rahmawati). Yogyakarta: Jalasutra. 